\title{
MARRIAGE, PERSONS, AND THE BODY: THOMISTIC INTIMATIONS IN KAROL WOJTYLA
}

\author{
Mark Joseph T. Calano \\ Ateneo de Manila University, Philippines
}

\begin{abstract}
Karol Wojtyta's understanding of marriage, persons, and the body operates within an unarticulated Thomistic presumption. While Thomas Aquinas did not explore persons, the conjugal act, and the body in the same way as Wojtyla did, correlating the two thinkers is mutually beneficial. The paper thematically looks into marriage, persons, and the body. The first part discusses the concept of marriage and the conjugal act. Based on this understanding, the person is clarified using Wojtyta's personalism and Thomas Aquinas's composite person. The second part demonstrates the concept of the incommunicability of persons as Wojtyta articulates it and intimates Thomas Aquinas. This notion leads us to the third part of the paper, which puts together the ideas of Thomas Aquinas and Wojtyta in order to argue for the relational nature of the body.
\end{abstract}

\section{INTRODUCTION}

Paul VI's encyclical, Humanae Vitae, encouraged contemporary philosophical and theological discussions on the concept of marriage and the conjugal act, persons, and the body; it is undeniable that this encyclical has encouraged Karol Wojtyła in his articulations of the theology of the body. While the ecclesial and phenomenological sources of Wojtyła's understanding of marriage and the conjugal act, persons, and the body are explicit, those intimated from Thomas Aquinas are not. In this paper, I use Wojtyła's pre-pontifical published works leading to the Theology of the Body and Thomas Aquinas's Summa Theologica as it is inspired by Thomas Petri (2016). The paper is divided into three parts following the themes: marriage and the conjugal act, persons, and the body; each theme engages the ideas of Karol Wojtyła and Thomas Aquinas. More than being exhaustive in determining Wojtyła's intimations of Thomas Aquinas, the article hopes to be representative and clarificatory of Wojtyła's, as informed by Thomas Aquinas's, understanding of the three aforementioned themes.

\section{MARRIAGE AND THE CONJUGAL ACT}

For Karol Wojtyła, as it is for Immanuel Kant, marriage is the only condition that makes possible the mutual giving of selves between and among sexes; this mutual 
giving of selves involves a relationship that is sexual in nature (1991, 211). Marriage is, in this sense, the social institution that is responsible for the protection of persons from being reduced to mere sexual objects; as such, it operates in a relational and committal nature, which also is the justification for the generating and rearing of children (1991, 216). Marriage is constituted by the maturation of the union between and among sexes and is the testimony to a community that is rooted and grounded in love $(1991,220)$; it is personal and communal commitment par excellence. It is "an objective framework for a lasting union of persons" and of communities $(1991,225)$; when applied to the conjugal act, it is "its own internal justification, for unless justice is done there can be no question of a union of persons" (1991, 225).

In marriage, as well as its correlative conjugal act, the natural and the personal orders both interact. The natural order does not only refer to nor is it reducible to the biological and the physiological orders only; it includes the totality of one's bodily and personal existence and the person's capability to procreate $(1991,226)$. In this natural order, the conjugal act is teleologically procreative. Marriage, then, is not only about the union of persons but is also "affected by the possibility of procreation" $(1991,226)$. It is in this sense that the natural order overlaps with the personal order to the point of being inseparable and correlative of each other (1991, 226). Not only is the conjugal act procreative, it also operates in the personal order as it separates and distinguishes us from animals. Wojtyła $(1991,226)$ explains:

In the animal world, there is only reproduction, which is achieved by way of instinct. In that world, there are no persons; hence there is no personalistic norm to proclaim the principle of love. In the world of persons, on the other hand, instinct alone decides nothing, and the sexual urge passes, so to speak, through the gates of the consciousness and the will, thus furnishing not merely the conditions of fertility but also the raw material of love.

In the above passage, Wojtyła distinguishes the conjugal act from mere sex (whether procreative or not). For him, the conjugal act, made possible by marriage, facilitates not only procreation (which is shared with animals) but the principle of love (which operates between and among persons).

In considering the conjugal act as procreative, the couple is open to the possibility of parenting. Like the natural and personal order cohering in the conjugal act, parenting cannot only be merely biological; it cannot be presumed automatic. Deeply ingrained in the parent and his or her parenting are themselves as persons; it involves one's person deeply, interiorly, and profoundly. Only a person can become a parent because it "implies the whole process of conscious and voluntary choice connected with marriage and with marital intercourse in particular" $(1991,227)$. Parenting is a choice tied to one's marital vows and the conjugal act. Because the conjugal act opens the possibility of procreation, it transcends the mere 'utilization for pleasure' and the reductive objectification of persons $(1991,228)$. In this sense, the sexual properties and the sexual urge resides at the very core of our humanity and are, in every instance of one's marital life, constant manifestations of one's person $(1993,284)$.

Wojtyła recognizes in the rational organization of persons a manifestation of an 
intrinsic norm. He understands this intrinsic norm to be a comprehensible and a discernible articulation of an order that is already in place and even governing the world $(1993,287)$. When these intrinsic norms are understood as laws, they become similar to Thomas Aquinas's teaching about laws. When we look at the relationship between the eternal and the natural law, Thomas argues that the rational faculty allows the person to participate in the eternal law and this participative consciousness is the natural law (particeps legis aeternae et conscia legis naturae) (1981, ST I-II, q. 91, a. 2.). Because reason plays an important role in the recognition of these normative structures for Wojtyła and Thomas, then only persons can discern them. When viewed in relation to marriage, it can be said that the teleological and procreative goal of the sexual urge and the conjugal act is only accessible to and between persons (Calano 2012).

The natural and teleological goal of the sexual urge is procreative; this is part of the normative structures (natural and personal order) of our personhood as it was already explained above and clarified further by Wojtyła $(1991,288)$ below:

The necessity of combining these two norms into one-which involves, of course, the necessity of properly situating the norm that emerges from an understanding of the purpose of the sexual urge within the objective content of the personalistic norm-is indispensable for preserving the order of nature.... In integral theological (as well as philosophical) reasoning in Catholic sexual ethics, the aims of nature must always come together with the value of the person.

Through these lenses, the sexual urge (as well as the conjugal act) can be understood as natural and as personal responses. The human person cannot simply fall victim to their natural urges at the expense of their personhood; integral in understanding this is the play between the natural and personal order. Wojtyła explains further: "the proper way for a person to deal with the sexual urge is, on the one hand, consciously to make use of it for its natural purposes, and on the other to resist it, when it threatens to degrade the relationship between two persons to a level lower than that of love, lower than the level on which the value of the person is affirmed in a union with a truly personal character" $(1991,229)$. More than subordinating a person to or becoming a victim of nature, Wojtyła argues that persons can adapt responsively and responsibly to the dynamics of nature.

Let us see how Thomas Aquinas intimated these ideas. Thomas Aquinas, like Augustine of Hippo, understands that the conjugal act is not only for purposes of procreation; it points to a marital relationship. As such, the conjugal act is not only part of the goods of marriage but presupposes the union of souls. For Thomas Aquinas, the pleasures that come with sex are not evil, even if they are a consequence of original sin. The conjugal act distinguishes a person's spousal love from their parental love (1981, II-II, q. 26, a. 11). Due to our fallen nature, the conjugal act can entail a vehement pleasure that overpowers reason and can at least be sinful venially; otherwise, it is meritorious (1981, II-II, q. 41, a. 4.). Thomas Aquinas recognizes reason as that which distinguishes us from animals even if it is impaired in the enjoyment of sleep and/or procreation (1981, II-II, q. 153, a. 1, ad 2). Taking it from Augustine, Thomas Aquinas refers to the three goods of marriages as fidelity, 
offspring, and the sacrament (1981, Supp., q. 49, a. 2.). These goods are not external factors that organize marriage or the conjugal act; instead, these are intrinsic and essential goods to the nature of marriage (1981, Supp., q. 49, a. 1, ad 2.).

While marriage makes the conjugal act possible, the act is not essential to the marital union (1981, Supp., q. 42, a. 4.). Understood as a consequence of marriage, Thomas Aquinas argues that marital consent constitutes marriage and this constitution includes the consent to the carnal union. He (1981, Supp., q. 48, a. 1.) explains:

The consent that makes a marriage is a consent to marriage because the proper effect of the will is the thing willed. Wherefore, according as carnal intercourse, stands in relation to marriage, so far is the consent that causes marriage a consent to carnal intercourse.... Marriage is not essentially the carnal union itself, but a certain joining together of husband and wife ordained to carnal intercourse, and a further consequent union between husband and wife, in so far as they each receive power over the other in reference to carnal intercourse, which joining together is called the nuptial bond.

The consent makes possible the conjugal act; it is not the conjugal act that proves consent. Thomas Aquinas explains that the conjugal act points to (or even makes possible) the three goods of marriage. While the conjugal act recognizes the generation and rearing of children as its teleological end, it is also indicative of fidelity of consent. In speaking of the fidelity of consent, the conjugal act signifies the indissolubility of the marital union (1981, ST, Supp., q. 42, a. 4, ad 2; cf. a. 1, ads 4-5).

Thomas Aquinas explains that consent gives the couple authority over each other's body. In the conjugal act, the couple is given the authority to procreate without reducing the partner to an object; Thomas Aquinas interprets this mutual right as marital debt (Gondreau 2008, 758-760). The marital debt makes possible the fidelity appropriate to the marital relationship (Calano 2016, 33-37.). Thomas explains: "Just as the marriage promise means that neither party is to have intercourse with a third party, so does it require that they should mutually pay the marriage debt (1981, Supp., q. 49, a. 2 , ad 3.). The spouses are obligated to pay the debt by making their bodies available to each other (1981, Supp., q. 64, aa. 1 and 5.). This authority over the spouse's body is evident when Thomas Aquinas bans a slave from marrying her master; the slave cannot offer her body freely to her husband (1981, Supp., q. 52, a. 1.). Thomas clarifies that the inability to engage in the conjugal act can render the marriage invalid because the spouse/s cannot freely offer his or her body to each other (1981, Supp., q. 58, a. 1.). This emphasizes the place of the conjugal act in marriage; Thomas Aquinas thinks: "Although the act of carnal copulation is not essential to marriage, the ability to fulfill the act is essential because marriage gives each of the married parties power over the other's body in relation to marital intercourse" (1981, Supp., q. 58, a. 1, ad 2.).

While the conjugal act is teleologically directed towards the generation and the rearing of children, it also has aspects beyond procreation. The marital debt suggests something more, and this includes the marriage's articulation of honesty and fidelityof love (1981, Supp., q. 64, a. 3.). Aquinas distinguishes sexual acts that are contrary 
to nature (contra naturem), and this includes sexual activities apart from the natural union of male and female, from conjugal and marital acts that are either procreative or per accidens (due to sterility, for example) non-procreative in the Summa contra Gentiles (1975, III.122.). For Thomas Aquinas and his language of sin, the sexual acts that are contrary to nature are always sinful, whereas marital acts that are either procreative or per accidens non-procreative are never sinful. We read this in a different light in the Summa Theologica (1981, Supp., q. 49, a. 5.):

Just as the marriage goods, in so far as they consist in a habit, make a marriage honest and holy, so too, in so far as they are in the actual intention, they make the marriage act honest, as regards those two marriage goods which relate to the marriage act. Hence when married persons come together for the purpose of begetting children or of paying the debt to one another (which pertains to faith), they are wholly excused from $\sin .$. . Consequently, there are only two ways in which married persons can come together without any sin at all, namely in order to have offspring and in order to pay the debt; otherwise, it is always at least a venial sin.

When the marital debt is understood in relation to lust, Thomas Aquinas insists that the conjugal act becomes vicious. Lust rides on in the goods intended for the spouse. He explains: "If the motive be lust, yet not excluding the marriage blessings, namely that he [the husband] would by no means be willing to go to another woman, it is a venial sin; while if he excludes the marriage blessings, to be disposed to act in like manner with any woman, it is a mortal sin" (1981, Supp., q. 41, a. 4.). The danger of lust is that it is interested in sexual pleasures alone, and it excludes the fulfillment of either the marital debt or that of procreation. In the words of Thomas Aquinas above, it is contra naturem as it reduces persons to mere instrumental goods. This is discernible in the faithfulness one owes their spouses:

If pleasure [in the conjugal act] be sought in such a way as to exclude the honesty of marriage, so that, to wit, it is not as a wife but as a woman that a man treats his wife, and that he is ready to use her in the same way if she were not his wife, it is a mortal sin; wherefore such a man is said to be too ardent a lover of his wife because his ardor carries him away from the goods of marriage. If, however, he seeks pleasure within the bonds of marriage so that it would not be sought in another than his wife, it is a venial sin (1981, Supp., q. 49, a. 6.).

The distinction between a mortal sin and a venial one, as explained by Thomas Aquinas, can be understood in relation to the treatment of spouses. If the spouses recognize the personhood of their partner, then it is not sinful. But, once the person of the spouse is clouded by lust and depending on the degree of objectification, then we see the distinction between mortal and venial sins: "if a man intends by the conjugal act to prevent fornication in his wife, it is no sin because this is a kind of payment of the debt that comes under the good of faith. However, if he intends to avoid fornication 
in himself, then there is a certain superfluity, and accordingly, there is a venial sin" (1981, Supp., q. 49, a. 5, ad 2.). While these are all focused on the motives of the husband (and, by association, that of his wife), Thomas Aquinas is keen on the tendency to reduce the spouse to an object and to the mere satisfaction of sexual desire.

Thomas Aquinas and Wojtyła look at marriage and the conjugal act as one that is proper to human spouses. While they emphasize different aspects of the marriage, as well as the conjugal act, it is undeniable that they both consider it as a good rooted in our personhood. Marriage and its consent are unitive in the same way that the conjugal act facilitates the goods that come with marriage. These discussions above are all possible only because we are persons. It is this understanding of persons and our incommunicability that is the concern of the next section.

\section{INCOMMUNICABILITY OF PERSONS}

The overlap between the natural and the personal order for Wojtyła, as well as the distinction between lustful activities for Thomas Aquinas, are all premised on the personhood of spouses recognized and affirmed by marriage. As such, the conjugal act is to be distinguished from any, if not all, sexual activities.

A woman and a man can afford each other pleasure of a sexual nature, can be for each other the source of various enjoyment. However, mere pleasure, mere sensual enjoyment, is not a good which binds and unites people for long.... A woman and a man, if their 'mutual love' depends merely on pleasure or self-interest, will be tied to each other just as long as they remain a source of pleasure or profit for each other. The moment this comes to an end, the real reason for their 'love' will also end, the illusion of reciprocity will burst like a bubble (Wojtyła 1991, 87).

Wojtyla clearly distinguishes between mere pleasure and enjoyment with the type of experience that love brings. More than merely the physical and psychological aspects of love, conjugal love carries an ethical import that is grounded and based on the dignity of persons. Because the spouses must go through the physical and the emotional aspects of love in order to consider the ethical aspect, then it makes sense why the good of a spouse also entails the good of the other (Wojtyła 1991, 90). Aside from arguing merely for the good of the other like Aristotle and Thomas Aquinas, Wojtyła expands this further and engages the concept of the incommunicability of persons (alteri incommunicabilis).

When two persons go beyond the physical and emotional aspects of love, they open themselves to the possibility of mutual self-giving. While the individuality and nature of persons are never compromised by such self-donation, Wojtyła explains, "what is impossible and illegitimate in the natural order and in a physical sense, can come about in the order of love and in a moral sense. In this sense, one person can give himself or herself, can surrender entirely to another, whether to a human person or to God" (1991, 96). Commitment is possible only at this level of self-giving. In the ordo amoris, the selfdonation is possible; in this self-giving, the self (inalienable, incommunicable, and non- 
transferable) is given and entrusted to the other $(1991,96)$. It is in the gift of love that we recognize the inalienable, incommunicable, and non-transferable " $\mathrm{I}$ " being surrendered to the person of the other $(1991,96)$. As such, the self-donation (similar to Thomas Aquinas and his understanding of the marital debt) cannot be merely sexual, or else it becomes vacuous and utilitarian (or in Thomistic terms - lustful).

In The Acting Person, Wojtyła articulates a way of understanding self-donation in a transcendental view of the human person $(1999,105-116)$. Willing the good is a form of determination. In this sense, a determination is never willed but is a means by which action, directly or indirectly, molds and shapes us. This self-determination cannot be understood merely as relativism even if Wojtyła asserts that self-knowledge and the cognitive understanding of reality guides volition (1999, 113-114); cognition puts together reality (then objectivized by cognition) and consciousness (the subjective experience of action) $(1999,114)$. By pointing to the transcendence of persons, Wojtyła shows us that we are more than volition and agency; neither action nor volition is sufficient and enough to perfect the human person $(1999,111)$.

Based on this transcendental understanding of persons, it is important to emphasize that, for Wojtyła $(1991,229)$ :

...the proper way for a person to deal with the sexual urge is, on the one hand, consciously to make use of it for its natural purposes, and on the other to resist it, when it threatens to degrade the relationship between two persons to a level lower than that of love, lower than the level on which the value of the person is affirmed in a union with a truly personal character.

Thus, Wojtyla affirms the natural purpose of the sexual urge. In a similar vein, it also affirms the human capacity to transcend the sexual urge especially if it no longer works in relation to love. This capability to transcend sexual urges tells us that persons are not slaves to natural inclination. As persons, we can adapt to the demands of our sexual urges; we can actualize them in the same way that we can transcend them. According to Wojtyła, human nature ceases when persons are violated $(1991,229)$. As such, Catholic ethics cannot simply be reducible to physicalism (biological and physiological requirements) (Wojtyła 1993, 290). We cannot be enslaved by sexual urges; we can transcend these desires because we are persons. While procreation is the teleological end of sexual desire, it also serves as mutual aid and a remedy for concupiscence. While the person is a moral norm for Wojtyła, Thomas Aquinas never used the word "person" to refer to humanity. For Thomas Aquinas, personhood is used only in his treatises on the Trinity and on the incarnation of Christ (1981, I, qq. 27-43, and III, q. 22.); this asserts the sacredness of persons.

In speaking about persons in relation to the Trinity and to Christ, Thomas Aquinas (1981, I, q. 29, a. 1.) notes that substances are unique and are individualized; he (1981, I, q. 29, a. 1, co.) further explains:

... in a more special and perfect way, the particular and the individual are found in the rational substances that have dominion over their own actions; and which are not only made to act, like others; but which can act themselves; for actions belong to singulars. Therefore also, the 
individuals of the rational nature have a special name even among other substances; and this name is person.

The above quote clarifies what persons as rational substances are able to do; it also asserts their particularity, singularity, and individuality. Hypostasis (first substance) refers to all subjects; 'person' signifies the same thing for all rational substances (1981, I, q. 29, a. 2, ad 2.). Concrete substances (whether rational or irrational) are given with nature or essence. Substance, nature, or essence refer to the "quiddity of a thing, signified by its definition, and thus we say that the definition means the substance of a thing" (1981, I, q. 29, a. 2, co.). In De Ente et Essentia, Thomas Aquinas emphasizes the significance of matter as the principle of similarity between similar species composed of matter and form (Torrell 1993/2006,47-50). Accidental qualities individuate substances. Thomas Aquinas explains that accidents are necessary for the existence of subjects (1981, III, q. 77, a.1, ad2.).

The accident is a principle of similarity for the same species and is the principle of difference among other species. Thomas Aquinas distinguishes accidents that are proper to both matter and form. The latter he calls "individual's accidents," and the former is referred to as "proper attributes" (1949, Ch. 6). Accidents differentiate primary matter from a particular matter. For Thomas Aquinas and Aristotle, gender is an individual accident consequent on matter (Ibid and Aristotle 1984, Metaphysics, $\mathrm{X} .9 .1058 \mathrm{~b} 21)$. The hypostasis of persons points to substances individualized by matter and designated by individual accidents. In this perspective, matter is considered the distinguishing principle of substance. Matter and form make possible the essence of things. Thomas Aquinas explains: "In things composed of matter and form, the essence signifies not only the form, nor only the matter, but what is composed of matter and the common form, as the principles of the species" (1981, I, q. 29, a. 2, ad3.). In the angelic realm, angels are different because of their powers and missions and not by virtue of their materiality; as such, they constitute an individual hypostasis of a rational nature and are therefore persons too (1981, I, q. 50, aa. 2, 4.).

The human person is embodied, but corpses are not persons. Thomas Aquinas writes: "The soul is part of the human species; and so, although it may exist in a separate state, yet since it ever retains its nature of unibility [with body and soul], it cannot be called an individual substance, which is the hypostasis or first substance, as neither can the hand nor any other part of man; thus neither the definition nor the name of person belongs to it" (1981, I, q. 29, a. 1, ad5.). The human person is both soul and body; we are neither body only nor soul only. Personhood is the perfection and manifestation of nature; nature and personhood are not contradictory. While we cannot fully know human nature, we can know persons. Unlike our knowledge of human persons, God is a person without a principle of limitation. Thomas Aquinas (1981, I, q. 29, a. 3, co.) explains:

Person signifies what is most perfect in all nature-that is, a subsistent individual of a rational nature. Hence, since everything that is perfect must be attributed to God, forasmuch as His essence contains every perfection, this name person is fittingly applied to God; not, however, as it is applied to creatures, but in a more excellent way. 
Thomas Aquinas distinguishes the personhood of God from human persons; he argues that God cannot be understood as an individualized matter. "God cannot be called an individual in the sense that His individuality comes from matter; but only in the sense which implies incommunicability" (1981, I, q. 29, a. 3, ad 4.). So while human persons are individualized by matter, as has already explained above, God is an individual (and thus a person), whom we can understand only in terms of his "incommunicability" par excellence (1981, I, q. 29, a. 3, co.). When we understand Wojtyła's appreciation and valuation of the person, we assert the presupposition of individuality, singularity, and particularity rooted, grounded, and shared with the sacredness and incommunicability of God. But, if persons are incommunicable as God is, how are we to understand the body and its spousal nature?

\section{SPOUSAL NATURE OF THE BODY}

Because God, who is a person, is characterized by incommunicability and incomprehensibility par excellence, so we share the same as persons created in the image of God (imago Dei). Wojtyła $(2001,76)$ explains:

Anybody can easily confirm the fact that man experiences in a profound way the fundamental inviolability of his person. He is conscious of belonging to himself, of possessing his own interior world of things, of plans, of decisions and of feelings, a whole interior life of which he is the owner and to which nobody else has access. He experiences his own personal individuality, autonomy, and unique character, and all come together in the profound consciousness of the inviolability of the person. For this reason, we can speak of the virginity of the human person. Man is a virgin by nature, in the sense that he possesses his own interior world, his own interior life which he himself shapes and which he alone is responsible.

If virginity is related to the inviolability of persons, then it is also tied to the understanding of bodies and the sexual urge. The sexual urge is the beginning of love and originates as a natural instinct in the body (1991, 45-51). The natural instinct directs persons to the person of the opposite sex as the object of desire; this is an affirmation of the so-called "complementarity of the sexes" (1991, 106-107). For love to be authentic, it needs to go beyond the body and find its end/home (terminus) in the person $(1991,123)$. In order to overcome the body and love the person, it has to be woven by virtue of chastity. Beyond the body, persons are endowed with the faculties of reason and volition, and these are integrated by the work of chastity.

Wojtyła's dependence on Thomas Aquinas is clear in his conceptualization of sensuality: "Any immediate contact between a woman and a man is always the occasion of a sensory experience for both of them. Each of them is a 'body,' [and] is therefore exposed to the senses of the other and creates some impression" (1991, 104). Sensuality includes the enjoyment of the spouses' body, and this enjoyment includes the pleasure that is the consequence of the conjugal act. Wojtyła does not exclude from the marital union the "“consumer orientation' directed primarily and immediately towards a 'body': 
it touches the person only indirectly, and tends to avoid direct contact" $(1991,105) . "$ When spouses are allowed to enjoy each other's personhood, and without guilt, then sensuality and love are understood in an integrated manner. When sensuality and love are separated and disintegrated, then spouses are objectified and utilized, but not loved.

The love between spouses is considered mature once it "is dominated by an ambition to possess, or more specifically by concupiscence born of sensual reactions, even if these are accompanied by intense emotion" (1991, 145). Love "develops on the basis of the totally committed and fully responsible attitude of person to person; erotic experiences are born spontaneously from sensual and emotional reactions" (1991, 145). Mature love can only be chaste; chastity overcomes the spontaneous erotic reactions between a man and a woman; it tames these reactions that reduce the other only for the enjoyment of the body. Chastity assures that the spouses as persons are loved. More than suppressing the pleasures of the body (which is considered good), Wojtyła explains that the "essence of chastity consists in quickness to affirm the value of the person in every situation, and in raising to the personal level all reactions to the value of "the body and sex"' $(1991,171)$.

Every person's innate desire for self-donation is based on our spiritual and metaphysical nature created as imago Dei, who is the perfect representation of love and communion (1991, 249-255). In the conjugal act, the couple's love and innate desires are fulfilled; this is true even if neither of the spouses possesses nor own each other. In the conjugal act, "the lover 'goes outside' the self to find a fuller existence in another" $(1991,126)$. The spouse, in a way, completes the other in a marital union. Wojtyła identifies two movements beyond human control: the somato-vegetative and the psycho-emotive movements $(1999,88-90)$. The somatic movement points to the human body; these movements are reactive to a stimulus $(1999,200)$. The somatic movements have two aspects: interiority and exteriority. By the movement of exteriority, Wojtyła explains: "the body is material, it is a visible reality, which is accessible to sense; the access to it is first of all from the "outside"' $(1999,200)$. Exteriority adopts a twofold purpose here: on the one hand, it considers the development of the self-image, and, on the other hand, it facilitates self- communication. Wojtyła explains: "It is generally recognized that the human body is in its visible dynamism the territory where, or in a way even the medium whereby, the person expresses himself' $(1999,204)$. The somatic movement is not reducible to the material body. The body is also composed of interior movement that refers to "the system and the joint functioning of all the bodily organs" (1999, 201/207). Wojtyła (1999, 208) explains:

The close connection existing between the human organism and nature, so far as nature constitutes the set of conditions of existence and life, helps us to define the somatic dynamism of man. It seems that this dynamism may be contained and expressed in the concept of reactivity and also by the attribute reactive... The human body has the ability to react like other bodies in nature.

Since the body is somatic, it responds to other bodies. However, it does not only respond to bodies, as it also responds to the freedom of the persons. Other than the soma is the psyche; psyche "apply to the whole range of manifestations of the integral 
human life that are not in themselves bodily or material, but at the same time show some dependence on the body, some somatic conditioning" (Wojtyła 1999, 201) In this case, the psyche is not always reducible to the soul; it is immaterial and dependent on the body (soma). For Wojtyła, psyche includes the consciousness of emotions in the person $(1999,222-223)$; as such, these are instinctive reactions that "are indicative of a dynamization that is appropriate to nature itself, while instinct with its inherent drive tells of nature's dynamic orientation in a definite direction" $(1999,215)$.

At the end of Love and Responsibility, Wojtyła asserts that "the drive of sex, which relies on the momentous division of mankind into male and female individuals, stems from the somatic ground and also penetrates deeply into the psyche and its emotivity, thereby affecting even man's spiritual life" $(1999,218)$. While the instinct for self-preservation is based on the survival instinct, the sexual instinct is rooted in "the desire for sharing with another human being" $(1999,218)$. Controlling this sexual desire is part of the larger process of human integration. This integration is, according to Wojtyła, necessary for human transcendence. Without integration and fragmentation, autonomy characterizes transcendence as impossible (1999, 106, 189-90, 220). For Wojtyła, integration entails self-possession and self-governance (1999, 189-199); it is the "subordination of the subjective ego to the transcendent ego - that is to say, the synthesis of efficacy and subjectiveness" $(1999,196)$. In relation to the discussion above, autonomy (or integration) includes the movements of the psyche and the soma and brings those movements to human agency $(1999,198-199)$. As is, Wojtyła humanism is fair as it recognizes the different aspects of our personhood: soma, psyche, sexuality, emotivity, among others; but we see the same with Thomas Aquinas.

Thomas Aquinas speaks of the human person as "composed of a spiritual and corporeal substance [qui ex spirituali et corporali substantia componitur]" (1981, I, prologue to q. 75.); the human person is composite. We are a substantial unity of body and soul. Even if the human soul subsists, it is not itself reducible to the human person. Humanity is greater than the soul. The human person is composite-body and soul:

To the nature of the species belongs what the definition signifies; and in natural things, the matter is part of the species; not, indeed, signate [that is, designated or particular] matter, which is the principle of individuality; but the common matter. For as it belongs to the notion of this particular man to be composed of soul, flesh, and bones; so it belongs to the notion of man to be composed of soul, flesh, and bones" (1991, I, q. 75, a. 4.).

Defining the human person as such necessitates the body and its resultant sexual differences. Thomas Aquinas clarifies an understanding of individual substances, where he situates sexual differences among those accidents inhering in matter. Sexual differences are individuating material attributes. As such, men and women have the same human nature. If sexual difference is rooted in materiality, then how can this affect the complementarity of sexes supported by marriage?

Love is a singular movement with "a twofold tendency": on the one hand, the love of friendship (amor amicitiae) and, on the other hand, the love of concupiscence (amor concupiscentia) (1981, I-II, q. 26, a. 4.). In discussing the love of friendship, Thomas Aquinas explains that it includes the movement "towards the good which a 
man wishes to someone, to himself or to another" (1981, I-II, q. 26, a. 4, ad 1). When one is loved with amor amicitiae, the person is loved as an end-in-itself. The love of concupiscence (amor concupiscentiae) refers to the goods that one wishes for another; this happens when that which is loved is loved only instrumentally (1981, I-II, q. 26, a. 4.). Thomas Aquinas notes the difference between these two loves in this way: "When we love a thing, by desiring it, we apprehend it as belonging to our well-being. In like manner when a man loves another with the love of friendship, he wills good to him, just as he wills good to himself: wherefore he apprehends him as his other self, in so far, to wit, as he wills good to him as to himself" (1981, I-II, q. 28, a. 1.). For him, marriage can be understood as a type of friendship: "The greater that friendship is, the more solid and long-lasting will it be.

Now, there seems to be the greatest friendship [maxima amicitia] between husband and wife, for they are united not only in the act of fleshly union, which produces a certain gentle association [suavem societatem] even among beasts but also in the partnership of the whole range of domestic activity" (1975, III.123, no. 6.). Thomas Aquinas develops Aristotle's understanding of the friendship of virtue as a means to describe the relationship between and among spouses; as such, it cannot constitute the friendships of mere utility and pleasure (Cf. 1984, Nicomachean Ethics VIII. 12.). Since friendship is virtuous, then marriage is considered perfect and indissoluble (1975, III.123, no. 6.); the indissolubility makes their love for one another more faithful (1975, III.123, no. 8.).

For Thomas Aquinas, the main purpose of marriage is the rearing and the education of children. This lifelong task necessitates that the parents live in a mutual bond (1981, II-II, q. 154, a. 2.). To this demand for a mutual bond, Thomas Aquinas, another feature to marriage--the union of souls. He (1981, III, q. 29, a. 2.) writes:

Now the form of matrimony consists in a certain inseparable union of souls, by which husband and wife are pledged by a bond of mutual affection that cannot be sundered. And the end of matrimony is the begetting and upbringing of children: the first of which is attained by conjugal intercourse; the second by the other duties of husband and wife, by which they help one another in rearing their children.

Interestingly, Thomas Aquinas's medieval and prophetic view considers sexual differentiation, but also gender equality and the union of souls. For him, the union of souls can be understood in relation to what many contemporary scholars refer to as the spousal nature/complementarity of the body.

Since the human person is a composite, the body cannot simply be the soul's physiological tool. The body and soul are both involved in agency as well as in thought; this is true even in the conjugal act. Like all created beings, human persons need to transcend one's self and find completion in another (and, ultimately, in the Other--God). This is evident in the conjugal act in humanity's natural existence, which requires the opposite sex for its teleological consummation. Because of Thomas Aquinas's understanding of marriage as friendship, there cannot be any complementarity without love. Because humans are created with bodies and souls, both elements are involved in seeking completion. This movement involves both the 
body and the soul - the human as a composite. This reaching out and complementarity with the other (both body and soul) is the meaning of Wojtyła's spousal meaning of the body; correlatively then, despite the differences in their sexual roles, Thomas Aquinas's asserts this argument when he claimed the equality of the spouses in marriage (especially in rendering the marital debt and the conjugal act, which was the material manifestation of this union).

\section{CONCLUSION}

The spousal meaning of the body is based on the relational nature of the body rooted in the freedom to love the other. Like Wojtyła, Thomas Aquinas argues for the composite relationship of the soul and the body. The person is not reducible to any of the two but is constituted and composed by both. Thomas Aquinas, like Augustine, agrees that every created being is seeking completion. This inherent desire-love - can be ordered in accordance with what is virtuous. In view of this, marriage is the exemplary form of friendship as it includes the voluntary exchange of consenting adults and the offering of each other's bodies. Because of the hylomorphic unity of humanity, the conjugal act can not simply be biological or procreative; it is also a personal one as it constitutes the payment of the marital debt and the rearing and education of offspring. Because Thomas Aquinas includes procreation and the rearing of offspring as the primary end of marriage, he develops the teleological importance of a reasonably enjoyed sexual pleasure and includes the fulfillment of the marital debt (understood as fidelity). The conjugal act may be considered an expression of the very union of souls that Thomas Aquinas came to believe marriage to be.

Wojtyła's contemporary understanding of marriage, persons, and the body, on the other hand, serve to address those lacking in Thomas Aquinas's medieval thought. His focus on the human person is a new addition to philosophical discourse, even when already intimated by Thomas Aquinas. In the modernity that followed after Rene Descartes, the renewed appreciation of the body provides a better understanding of the difference and the relationship between men and women. Even if the body cannot fully express the uniqueness of every human person, it is, for Wojtyla and Thomas Aquinas, a good starting point. While Wojtyła goes beyond the idea of Thomas Aquinas, he does not reject it; instead, he grounds and roots himself in Thomas Aquinas in order to develop it further.

\section{REFERENCES}

Aquinas, Thomas. 1949. Opusculum de ente et essentia. Turin: Marrietti, 1948. Translated by Armand Maurer as On Being and Essence. Toronto: Pontifical Institute of Medieval Studies.

Aquinas, Thomas. 1975. Summa contra Gentiles. Opera Omnia 13-15. Rome: Riccardi Garroni, 1918-30. Translated by A. C. Pegis, J. F. Anderson, V. J. Bourke, and C. J. O’Neil as Summa contra gentiles. 4 vols. South Bend, Indiana.: University of Notre Dame Press.

Aquinas, Thomas. 1981. Summa Theologiae. Torino: Edizioni San Paolo, 1962. 
Translated by the Fathers of the English Dominican Province as Summa theologiae. Allen, Tex.: Christian Classics.

Aristotle. 1984. The Complete Works of Aristotle: The Revised Oxford Translation. Edited by Jonathan Barnes. 2 vols. Princeton, N.J.: Princeton University Press.

Calano, Mark Joseph. 2016. Marriage and conjugal act: Paul's 'Marriage Debt' and Kant's 'Conjugal Rights.' Perspectives in the Arts and Humanities Asia. 6.1:31-46. Calano, Mark Joseph. 2012. Participatio Legis Eternae. In ACTA: Proceedings of the Quadricentennial International Philosophy Congress. Edited by Alfredo Co and Paolo Bolaños. Manila: University of Santo Tomas Publishing House: 165-173.

Gondreau, Paul. 2008. The 'Inseparable connection' between procreation and unitive love (Humanae Vitae, §12) and Thomistic hylemorphic anthropology. Nova et Vetera (English Edition) 6: 731-64.

Torrell, Jean-Pierre. 1996/2003. OP. Saint Thomas Aquinas. 2 vols. Translated by Robert Royal. Washington, D.C.: The Catholic University of America Press.

Petri, Thomas. 2016. Thomas Aquinas and the Theology of the Body: The Thomistic foundations of John Paul II's anthropology. The Catholic University of America Press. Washington, D.C.

Wojtyła, Karol. 1991. Love and responsibility. Translated by H. T. Willets. San Francisco, California: Ignatius Press.

Wojtyła, Karol. 1993. The problem of Catholic sexual ethics: Reflections and postulates. In Person and Community: Selected Essays. Translated and edited by Teresa Sandok. New York: Peter Lang: 279-99.

Wojtyła, Karol. 1999. The acting person. Translated by Andrzej Potocki. Boston: D. Reidel Publishing Company.

Wojtyła, Karol. 2001. La experiencia religiosa de la pureza." In El Don del Amor: Escritos Aobre la Familia. Translated by Antonio Esquivias and Rafael Mora. 2nd ed. Madrid: Ediciones Palabra: 69-81. 